\title{
ANALISIS FAKTOR - FAKTOR YANG MEMPENGARUHI PERILAKU KONSUMEN TERHADAP PEMBELIAN PRODUK MAKANAN BERBAHAN DASAR HASIL TERNAK DI WILAYAH KOTA LAMONGAN
}

\author{
M. Fathul Amin ${ }^{1)}$, Edy Susanto ${ }^{2)}$ dan Nuril Badriyah. ${ }^{3}$ \\ 1) Program Studi Peternakan Fakultas Peternakan Universitas Islam Lamongan \\ 2) dan 3) Fakultas Peternakan Universitas Islam Lamongan \\ JI.Veteran No.53.A Lamongan
}

\begin{abstract}
ABSTRAK
Pengumpulan data penelitian dilakukan pada 27 Juni hingga 26 Juli 2015 di Pasar Sidoharjo, Pasar Made, Alfamidi Veteran, Indomaret Made Fauzi, agen makanan beku, makanan beku Agen Bapak Nur. Tujuan penelitian ini adalah mengetahui produk makanan apa yang dibuat dari ternak yang beredar di kota Lamongan dan untuk mengetahui bagaimana pengaruh faktor-faktor yang mempengaruhi perilaku konsumen dalam membeli produk pertanian. Hasil penelitian menunjukkan bahwa produk makanan berbasis daging ada 69 macam, produk makanan yang terbuat dari telur ada satu spesies, produk makanan berbasis susu ada 130 jenis. Variabel pendidikan memiliki pengaruh positif dan signifikan terhadap keputusan pembelian produk pangan berbasis ternak $(\mathrm{Y})$ pada taraf signifikansi $95 \%$ atau $\alpha=$ $0,05(p<0,05)$, dengan koefisien regresi (bi) sebesar 0,071 hingga 0,000 signifikansi $(p<0,05) .<0,05)$, variabel pendapatan memiliki pengaruh positif dan signifikan terhadap keputusan pembelian berdasarkan produk makanan ternak $(Y)$ pada taraf signifikansi 95\% atau $\alpha=0,05(p<0,05)$, dengan koefisien regresi (bi) sebesar 0,174 sampai 0,000 signifikansi $(p<0,05)$, variabel sumber daya memiliki pengaruh positif dan signifikan terhadap keputusan pembelian berdasarkan produk pangan ternak $(Y)$ pada taraf signifikansi $95 \%$ atau $\alpha=0,05$ ( $p<0,05$ ), dengan koefisien regresi (bi ) dari 0,025 hingga 0,000 signifikansi ( $p<0,05$, variabel gaya hidup memiliki pengaruh positif dan signifikan terhadap keputusan pembelian berdasarkan produk makanan ternak $(Y)$ pada taraf signifikansi $95 \%$ atau $\alpha=0,05(p<0,05)$, dengan koefisien regresi ( bi) dari 0,676 hingga 0,000 significanc e $(p<0,05$.
\end{abstract}

Kata Kunci : Perilaku konsumen, Produk makanan, Hasil ternak, Lamongan

\section{PENDAHULUAN}

Proses pemilihan produk peternakan untuk dikonsumsi oleh masyarakat, dapat dipengaruhi oleh beberapa hal, antara lain: a) tingkat perbedaan karakteristik individu, yaitu tingkat pendapatan, pengetahuan, pengalaman, gaya hidup dan komunitas pergaulan; b) pengaruh eksternal, antara lain status sosial keluarga dalam masyarakat, latar belakang budaya dan kebiasaan masyarakat; c) pengaruh lingkungan; d) program kampanye atau promosi baik oleh pemerintah maupun pihak swasta, serta e) pengaruh dari atribut (image) yang melekat pada produk itu sendiri, yakni kebersihan, kesehatan, penampilan, kandungan gizi, keamanan, kemudahan diperoleh, rasa, mutu, kualitas, kepraktisan dan harga dari produk tersebut (Setiabudi et al., 1999 dalam Bakrie, dkk., 2008).

Penilaian konsumen terhadap produk atau jasa menggambarkan sikap konsumen terhadap produk dan jasa tersebut, sekaligus dapat mencerminkan perilaku konsumen dalam menggunakan atau mengkonsumsi suatu produk atau jasa. . Konsumen mengambil keputusan untuk menunda atau menghindari keputusan pembelian sangat dipengaruhi oleh risiko yang dipikirkannya, sehingga besarnya risiko tergantung pada besarnya uang yang dipertaruhkan, besarnya ketidakpastian atribut, dan besarnya kepercayaan diri konsumen sehingga untuk mengurangi risiko tersebut, konsumen melakukan beberapa hal seperti menghindari keputusan pembelian, mengumpulkan informasi dari teman dan perilaku atas produk yang akan dibelinya, oleh karena itu informasi tentang keadaan saat ini dalam hal perilaku konsumen di wilayah kota Lamongan.

\section{PERUMUSAN MASALAH}

1. Apa saja produk makanan berbahan dasar hasil ternak yang beredar di wilayah kota Lamongan?

2. Bagaimana pengaruh faktor perilaku konsumen dalam membeli produk peternakan? 
sampel berdasarkan pada kriteria-kriteria tertentu (Siregar, 2012).

\section{TUJUAN PENELITIAN}

1. Mengetahui apa saja produk makanan berbahan dasar hasil ternak yang beredar di wilayah kota Lamongan.

2. Mengetahui bagaimana pengaruh faktor perilaku konsumen dalam membeli produk peternakan.

\section{METODOLOGI PENELITIAN}

Penelitian ini dilakukan pada tanggal 27 Juni - 26 Juli tahun 2015. Lokasi penelitian dilaksanakan di enam sampel lokasi di Kota Lamongan adalah Pasar Tradisional Sidoharjo, Pasar Tradisional Made, Indomaret Made, Alfamidi Veteran, Agen makanan beku Bapak Nur Kranggan dan Agen makanan beku Bapak Fauzi Made yang berada di Wilayah Kota Lamongan.

Teknik penelitian yang digunakan adalah penelitian survey. Penelitian survey adalah penelitian yang mengambil sampel dari suatu populasi dan menggunakan kuesioner sebagai alat pengumpulan data yang pokok (Sugiyono, 2014).

Pengambilan sampel dengan purposive sampling dan convinience sampling, metode pengambilan sampel dengan purposive sampling adalah metode penetapan responden untuk dijadikan

\section{HASIL DAN PEMBAHASAN}

Produk Makanan Berbahan Dasar Daging

Produk makanan berbahan dasar daging yang beredar diwilayah Kota Lamongan dapat dilihat pada gambar berikut :

Dari gambar 1 dapat dilihat bahwa produk sosis memiliki varian jenis produk yang tertinggi yang beredar di wilayah Kota Lamongan yaitu sebesar 21 varian jenis produk.

\section{Produk Makanan Berbahan Dasar Telur}

Produk makanan berbahan dasar daging yang beredar diwilayah Kota Lamongan dapat dilihat pada gambar berikut :

Dari gambar 2 dapat dilihat bahwa produk makanan berbahan dasar hasil ternak, yang beredar diwilayah Kota Lamongan hanya berupa telur asin.

\section{Produk Makanan Berbahan Dasar Susu}

Produk makanan berbahan dasar daging yang beredar diwilayah Kota Lamongan dapat dilihat pada gambar berikut

Gambar 1. Data jumlah jenis produk makanan berbahan dasar daging

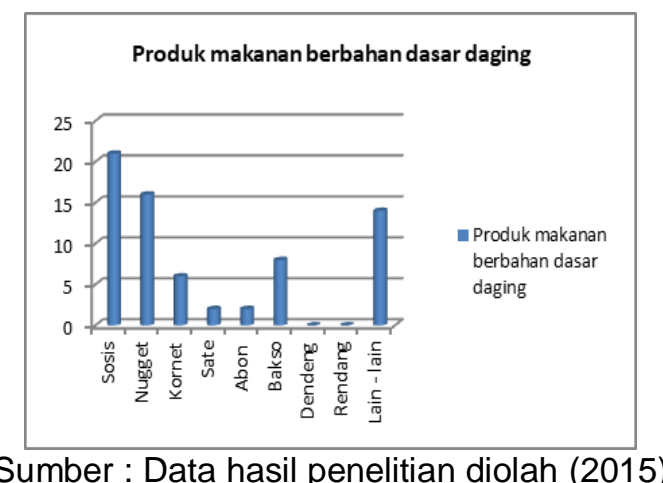

Sumber : Data hasil penelitian diolah (2015)

Gambar 2. Data jumlah jenis produk makanan berbahan dasar telur

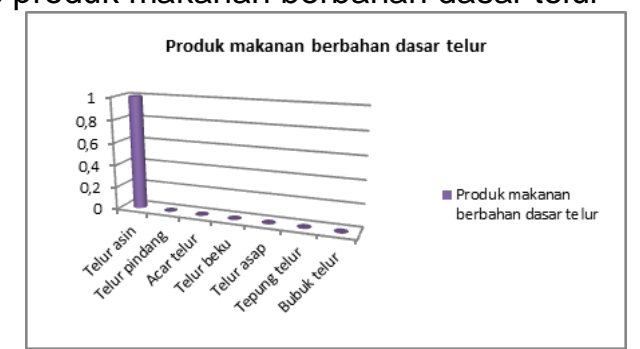

Sumber : Data hasil penelitian diolah (2015) 
Gambar 3. Data jumlah jenis produk makanan berbahan dasar susu

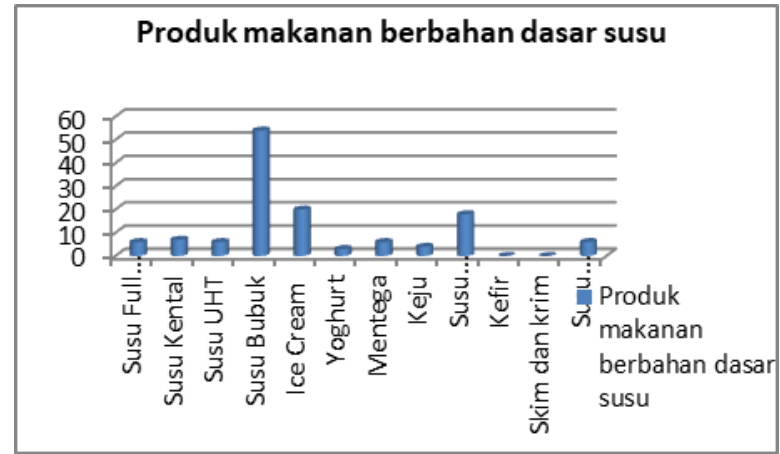

Sumber : Data hasil penelitian diolah (2015)

\section{Analisa Regresi Linear Berganda}

Tabel 1. Output Analisa Regresi Linier Berganda

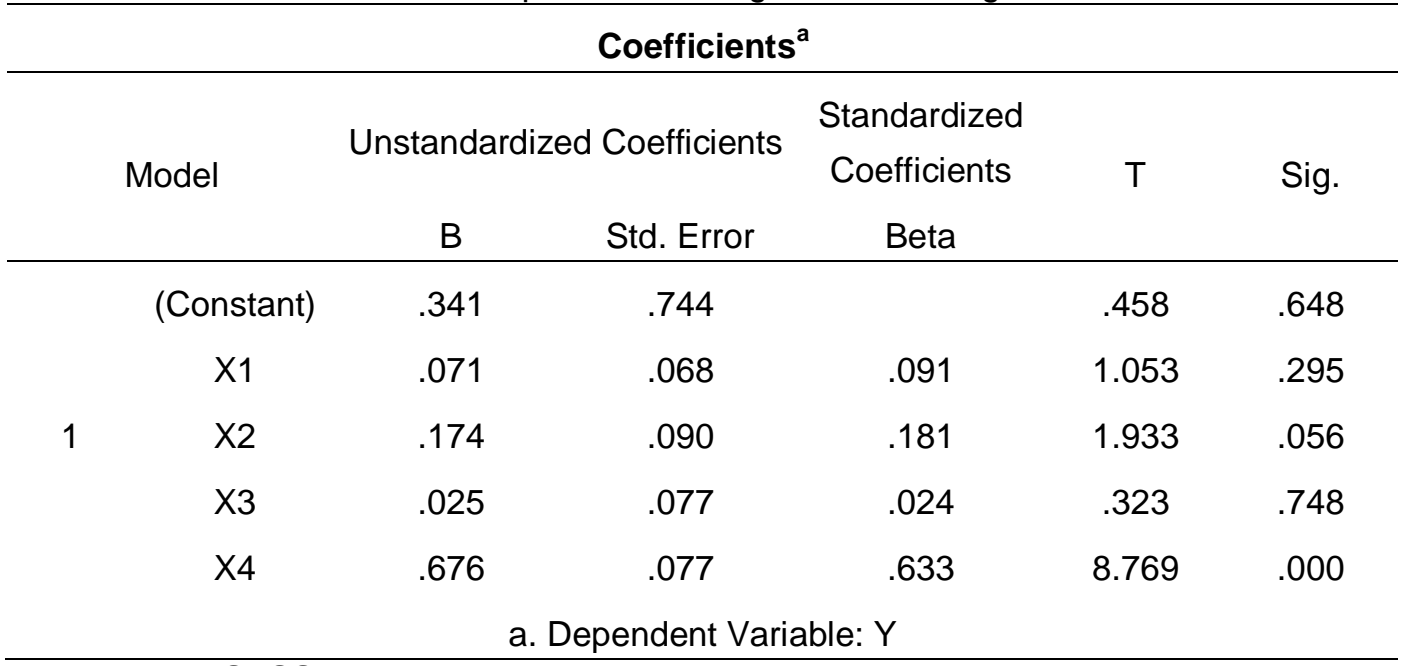

\section{Sumber : Output SPSS 17.0}

Analisa regresi linear berganda dalam penelitian ini, dihitung dengan menggunakan program SPSS 17 for Windows.

Regresi berganda $=$

$Y=0,341+0,071 X_{1}+0,174 X_{2}+0,025 X_{3}+$ $0,676 \mathrm{X}_{4}$, yang diartikan sebagai berikut :

$\mathrm{a}=$

$\mathrm{X} 1=0,071$ artinya apabila pendidikan naik sebesar 1 poin maka keputusan pembelian produk makanan berbahan dasar hasil ternak akan meningkat sebesar 0,071 dengan asumsi bahwa nilai koefisien variabel yang lain (semua variabel yang mempengaruhi keputusan pembelian produk makanan berbahan dasar hasil ternak) adalah tetap atau (a, x2, x3, x4 =0) Hal ini didukung oleh pendapat Khomzan (2006) dalam Nawawi (2013) yang menyatakan bahwa orang yang berpendidikan lebih tinggi cenderung memilih makanan yang lebih baik dalam jumlah dan mutunya dibandingkan mereka yang berpendidikan lebih rendah. Hal ini disebabkan karena orang yang berpendidikan tinggi memiliki tingkat

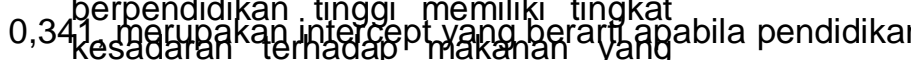
bernilai gizi tinggi.

X2 $=0,174$, artinya apabila Pendapatan naik sebesar 1 poin maka keputusan pembelian produk makanan berbahan dasar hasil ternak akan meningkat sebesar 0,174, dengan asumsi bahwa nilai koefisien variabel yang lain (semua variabel yang keputusan pembelian produk makanan berbahan dasar hasil ternak) adalah tetap atau $(a, x 1, \quad x 3, \quad x 4=0)$. Penghasilan seseorang dengan pendapatan yang 
tinggi cenderung untuk mendorong perilaku dalam mengkonsumsi suatu produk. Semakin tinggi pendapatan seseorang, maka semakin tinggi jenis dan jumlah barang yang akan dibeli (Haliana, 2009 dalam Darwanti, 2014).

X3 $=0,025$, artinya apabila Sumber informasi naik sebesar 1 poin maka keputusan pembelian produk makanan berbahan dasar hasil ternak akan meningkat sebesar 0.025 , dengan asumsi bahwa nilai koefisien variabel yang lain (semua variabel yang keputusan pembelian produk makanan berbahan dasar hasil ternak) adalah tetap atau $(a, x 1, x 2, x 4=0)$. Hal Ini sesuai dengan pendapat (Arifin, 2012) bahwa iklan mempunyai peran yang sangat kuat dalam membujuk konsumen yang terjaring dalam lingkarannya terbius untuk mengikuti produk yang diinformasikan

X4 $=0,676$, artinya apabila Gaya Hidup naik sebesar 1 poin maka keputusan pembelian produk makanan berbahan dasar hasil ternak akan meningkat sebesar 0,676, dengan asumsi bahwa nilai koefisien variabel yang lain (semua variabel yang keputusan pembelian produk makanan berbahan dasar hasil ternak) adalah tetap atau $(a, x 1, x 2, x 3=0)$. Hal ini didukung Setiawan (2015), bahwa gaya hidup berpengaruh signifikan terhadap keputusan pembelian.

Besarnya koefesien variabel Pendidikan, Pendapatan, Sumber informasi dan Gaya hidup sangatlah berarti hal ini seperti dijelaskan bahwa probabilitas kesalahannya $<\alpha$ yaitu pada $X_{1}=0,295, X_{2}=$ $0,056, X_{3}=0,748, X_{4}=0,676$ sehingga keempat variabel tersebut mempunyai nilai yang signifikan terhadap keputusan pembelian produk makanan berbahan dasar hasil ternak.

\section{KESIMPULAN}

Berdasarkan uraian hasil penelitian dan pembahasan dapat disimpulkan :

1. Hasil penelitian menunjukkan bahwa produk makanan berbahan dasar daging ada 69 jenis, produk makanan berbahan dasar telur ada 1 jenis, produk makanan berbahan dasar susu ada 130 jenis.

2. Perilaku konsumen menunjukan bahwa, semua variabel memiliki memiliki pengaruh positif dan signifikan terhadap terhadap keputusan pembelian produk makanan berbahan dasar hasil ternak $(\mathrm{Y})$ pada tingkat signifikasi $95 \%$ atau $\alpha=$ $0,05(p<0,05)$, dengan persamaan $Y=$ $0,341+0,071 X_{1}+0,174 X_{2}+0,025 X_{3}+$ $0,676 X_{4}$

\section{DAFTAR PUSTAKA}

Adhiyasa, Idkham. 2012. Kandungan Gizi. http://www.organisasi.org/1970/01/k andungan-gizi.html. Diakses pada tanggal 12 Maret 2015. 20.00 WIB.).

Andini Prisca. 2012. Analisis Faktor-Faktor yang Mempengaruhi Keputusan Pembelian Mobil Hyundai i20. Semarang. Skripsi. Fakultas Ekonomika dan Bisnis Universitas Diponegoro.

Anonim. 2015. Kandungan Gizi. http://Nutritiondata.self.com/facts/dai ry-and-egg products/132/2. Diakses pada tanggal 18 Maret 2015. $02: 33$ WIB.

Arifin, Adiyatma. 2012. Pengaruh Periklanan Terhadap Pembelian Konsumen Pasta Gigi Pepsodent Di Kota Makassar. Skripsi. Makassar : Jurusan Manajemen Fakultas Ekonomi Universitas Hasanuddin Makassar.

Bakrie, Bachtar, Suwandi, D. Setiabudi dan Sarjoni. 2008. Analisis Faktor Yang Mempengaruhi Preferensi Konsumen Terhadap Produk Peternakan Di Wilayah Perkotaan DKI Jakarta. Jakarta: Balai Pengkajian Teknologi Pertanian Jakarta.

Burhanuddin Abdillah. 2011. Analisis Perilaku Konsumen Pada Pembelian Daging Ayam Ras (Broiler Chicken) Di Pasar Traditional dan Pasar Modern Kota Jember. Jember. Jurusan Sosial Ekonomi Pertanian Fakultas Pertanian Universitas Jember.

Darwanti. 2014. Analisis Pengaruh Bauran Pemasaran Terhadap Keputusan Pembelian Dalam Membeli Telur Asin "Chozin" Dan "Rahayu" Di Kecamatan Babat Kabupaten 
Lamongan. Skripsi. Fakultas Peternakan Universitas Brawijaya Malang. Diakses 7 juni 2015.

Dwiastuti Rini, Agustina Shinta dan Riyanti Isaskar. 2012. IImu Perilaku Konsumen. Malang. Universitas Brawijaya Press.

Setiawan, Brian Bayu. 2015. Pengaruh Gaya Hidup Terhadap Pembelian Rumah. Skripsi. Semarang : Fakultas Ekonomi Dan Bisnis Universitas Dian Nuswantoro.

Hapsari, Paramita, 2007, Identifikasi Komoditi Pertanian Unggulan di Kabupaten Semarang, Skripsi. Surakarta: Fakultas Pertanian Universitas Sebelas Maret.

Herawati, diah yani, Hari dwi utami, Budi Hartono. 2013. Preferensi Konsumen Terhadap Pembelian Telur Ayam Ras di Kota Mojokerto. Malang : Fakultas Peternakan Universitas Brawijaya.

Nawawi, Mahardiana. 2013. Pengaruh Faktor Fungsional Dan Faktor Personal Konsumen Terhadap Keputusan Pembelian Ayam Ras Petelur Afkir Dipusat Niaga Daya, Kota Makasar. Skripsi. Makassar. Jurusan Sosial Ekonomi Peternakan Fakultas Peternakan Universitas Hasanuddin.

Nazir Mohammad. 2009. Metode Penelitian. Bogor. Ghalia Indonesia.

Ririn Tiyani Dwinta. 2012. Analisis Bauran Promosi Dalam Meningkatkan Volume Penjualan Mobil Daihatsu Pada PT. Jujur Jaya Sakti Makassar. Skripsi. Makassar. Jurusan Manajemen. Fakultas Ekonomi dan Bisnis Universitas Hasanuddin.

Sutrisni. 2010. Analisis Pengeruh Kualitas Produk, Kualitas Pelayanan. Desain Produk. Harga dan Kepercayaan Terhadap Loyalitas Pelanggan Indosat IM3 Pada Mahasiswa Fakultas Ekonomi Universitas Diponegoro. Skripsi. Semarang. Fakultas Ekonomi Universitas Diponegoro.
Sugiyono. 2014. Metode Penelitian Manajemen. Yogyakarta. Alfabeta.

Siregar Syofian. 2012. Statistik Parametrik Untuk Penelitian Kuantitatif. Jakarta. PT. Bumi Aksara.

Sutaryo dan Sri Mulyani. 2004. Pengetahuan Bahan Olahan Hasil Ternak dan Standar Nasional Indonesia. Ungaran. Universitas Diponegoro.

Suharyanto. 2009. Pengolahan Bahan Pangan Hasil Ternak. Bengkulu. Jurusan Peternakan Fakultas Pertanian Universitas Bengkulu 